\title{
THE TECHNIQUES OF TEACHING BUSINESS ENGLISH TO THE STUDENTS OF LINGUISTICS MAJOR
}

Natalia Nikolaevna Bobyreva Kazan Federal University, Kazan, Russia.

Karina Muratovna Amirkhanova Kazan Federal University, Kazan, Russia.

E-mail: nathalienb@yandex.ru

Recepción: 05/08/2019 Aceptación: 09/09/2019 Publicación: 23/10/2019

\section{Citación sugerida:}

Bobyreva, N.N. y Amirkhanova, K.M. (2019). The techniques of teaching Business English to the students of linguistics major. 3C TIC. Cuadernos de desarrollo aplicados a las TIC. Edicion Especial, Octubre 2019, 90-105. doi: https://doi.org/10.17993/3ctic.2019.83-2.90-105

\section{Suggested citation:}

Bobyreva, N.N. \& Amirkhanova, K.M. (2019). The techniques of teaching Business English to the students of linguistics major. 3C TIC. Cuadernos de desarrollo aplicados a las TIC. Special Issue, October 2019, 90-105. doi: https://doi.org/10.17993/3ctic.2019.83-2.90-105 


\section{ABSTRACT}

The article describes the principles and methods of teaching Business English to the intending interpreters, translators and English teachers. The necessity to study the techniques of teaching it is conditioned by the importance of the English language as a means of international communication in the professional sphere. The authors of the article describe their experience in Business English teaching at the Higher School of Foreign Languages and Translation of Kazan (Volga Region) Federal University. The process of teaching Business English is designed to improve the students' knowledge of business terms, idioms; to improve the related language, communication and translation skills; to prepare for international certification; to develop motivation and leadership. The survey results and observation make it possible to conclude that learning Business English is one of the most significant components in the linguistic professional education, which is recommended to be included into the list of obligatory academic subjects.

\section{KEYWORDS}

Language, Linguistics, Learning, Student, Business English. 


\section{INTRODUCTION}

Different issues of university language education are within the focus interest of researchers. Finding effective educational approaches is possible via combining the classic and modern teaching-learning methods (Sirbu et al., 2015; Kheirabadi \& Mirzaei, 2019). The effectiveness of using integrated technologies, flipped learning and other innovative approaches and methods in the educational process is widely discussed (Abdullina et al., 2019; Kondrateva \& Nazarova, 2015; Kashisaz \& Mobarak, 2018). Electronic resources also serve as modern educational aids, which help to learn a subject in different aspects and develop skills, structuring and representing the full content of the subject, providing a wide range of task types and corresponding references (Akimova et al., 2015; Kurbanov et al., 2017; Nakhaee \& Nasrabadi, 2019).

Concerning the urgency of the present research, on the one hand, it is obvious that the significance of learning Business English in the modern world is out of question. Teachers and methodologists all over the world have created a lot of materials and tested various methods of teaching Business English. However, there are still some problematic issues, which concern teaching this subject to the students of linguistics major, i.e. future translators, interpreters and teachers of foreign languages.

Teaching this category of students presupposes the development of not only general cultural, linguistic and communicative competences, but also professional competences. For example, future translators are supposed to be able to translate texts connected with the business sphere, and future teachers are expected to have a clear understanding about how to teach Business English to different kinds of learners. Consequently, it can be argued that the process of teaching Business English to the students of linguistics major has its peculiarities. Firstly, as this category of students have no experience in business, teaching this subject could be regarded as soft CLIL (Bentley, 2011; Eslami \& Ahmadi, 2019; Mahdavi Panah \& Ghaderi, 2018). Besides, linguists are specialists in the sphere of intercultural 
communication, and it is hard to exaggerate their responsibility in completing the task of communicating successfully in the multicultural world (Zorina et al., 2016; Jabbari et al., 2019; Pussyrmanov et al, 2018).

\section{METHODS}

Business English related subjects are studied by the bachelor's degree students (the 3rd and 4th years of studies) and by master's degree students of linguistics major at Kazan (Volga Region) Federal University. These courses are optional, and the options are given to the students at the stage, when they have already mastered General English at the Upper-Intermediate level, when they have passed the obligatory theoretical courses of language theory, lexicology and translation studies. Learning these subjects is reasonable mostly for senior students, because they have enough knowledge and skills, and the necessity of finding a job is becoming urgent for them. Students already have a full idea about their future profession, they have their own view of all the aspects of their future professional activity.

There was a survey among 86 bachelor's and master's degree students of 7 academic groups. The programmes of their studies are: Translation and Translation Studies (bachelor's degree); Theory and Methods of Teaching Foreign Languages and Cultures (bachelor's and master's degrees); Management in Linguistic Education (master's degree). All the respondents study English as a second language. One of the targets of the survey was to get feedback, showing students' satisfaction with the quality of their curriculum and, thus, of the education they are getting, which is important in terms of independent evaluating of education quality (Yanova, 2015).

The students were asked to answer four questions: 1. How important it is to know Business English for your future profession? 2. Do you plan to translate in the business sphere? 3. How essential is it to pass the international certification in Business English for translators, interpreters and English teachers? 


\section{RESULTS AND DISCUSSION}

\subsection{LEARNING BUSINESS ENGLISH AS A SEPARATE ACADEMIC SUBJECT}

The aim of this subject is the development of a competence to communicate in a business environment. The content of this academic course includes the following areas:

1. "Basic notions of Business English", presenting Business vocabulary, grammar features, language skills useful for business, business-related topics;

2. "The style of official documents", introducing basic lexical, morphological, syntactical and compositional features;

3. "Translating bureaucratic style", covering the most essential peculiarities of the translation process in the corresponding sphere and the characteristics of the style influencing it, such as accuracy, standard character, directive character, impersonality, clear structure (Proshina, 2008).

4. "International certification in Business English", introducing the general information about Business English exams, their types and levels;

5. "Types of business letters and documents" covering the issues of business correspondence; the rules of making up contracts, CVs; writing application, request, credit, sales promotion letters; writing claims and adjustments, memos, emails, proposals and reports; maintaining joint venture correspondence and correspondence between colleagues in scientific spheres.

The topics of the practical classes are as follows: "Careers", "International Payments and Credits", "Contracts", "Marketing", "Business Management" and "Business Law". For each of the topics students do the following:

- learn a glossary with definitions;

- do lexical exercises; 
- $\quad$ read, retell, summarize, translate original texts;

- do reading tasks: answer questions, presupposing true/false marking or extended explanations;

- make up monologues and dialogues, employing role-play in typical situations of business communication, such as a job interview, project presentation, discussions with colleagues, negotiations;

- do writing tasks: letters, memos, emails, etc.

Thus, they train four language skills (reading, writing, listening and speaking) in relation to Business English.

One of the most important tasks of the discipline is to acquaint students with terms employed in the process of business communication. They learn basic economic and legal terminology. The examples are as follows:

- $\quad$ simple terms: assets; commodity, equity, inventory, liabilities, payables;

- compound terms: cash advance, currency conversion, market segmentation, mission statement, net profit, tax refund;

- business idioms: game plan, upper hand, learn the ropes, raise the bar, see eye to eye, ahead of the curve;

- abbreviations: $\boldsymbol{C M}$ contribution margin; $\boldsymbol{C} \boldsymbol{C V S}$ Credit Card Verification System; MPS master production schedule; OMS Order Management System.

The following types of vocabulary exercises are used: word formation; matching words to make collocations; gap filling; matching words with their definitions; deciphering abbreviations; translating phrases and sentences from English to Russian and vice versa.

During the term, every student compiles their own English-Russian Glossary of Business Terms, which is one of the final assessment tasks. Students include the vocabulary, which is regarded as new personally by them, study a dictionary example sentence and make up one of their own. 
Giving their answers to the first question of the questionnaire, about the importance of Business English for their future career, the vast majority (95\%) of respondents said that Business English skills are necessary for any linguist, but mostly for a translator or interpreter. $38 \%$ of the respondents are sure that such language skills play a great role regardless of what job they will have in future. Business English knowledge and skills tend to be regarded not as professional competences, but as indicators of education, background, social status, and means of successful communication.

As for merely professional skills, the students mentioned the importance of the abilities to draw up documents, use business etiquette, communicate correctly with colleagues, partners and clients. According to the survey results, nearly half of the respondents could be interested in the job involving translating texts in the sphere of business, and they noted the importance of general erudition and special knowledge in the relevant field.

\subsection{EXAM PREPARATION FOR BUSINESS ENGLISH CERTIFICATE}

The modern labour market dictates the necessity to be professionally competitive and have an internationally recognized evidence of competences. Besides, such a recognition is needed in case of getting further education abroad.

The market environment demands teaching youth to demonstrate emotional intelligence and leadership skills, which is possible via developing their organizational inclination and communication skills (Zorina et al., 2018). To meet this social demand, a few international exams training courses were introduced for the 4th year bachelor's degree students, as well as for master's degree students. The respective disciplines are called Preparation for CAE, IELTS (Academic), BEC and TOEFL. Those are optional courses, which means that one of them is chosen by an academic group. So, BEC is the examination focused on Business English skills. 
The course for bachelors contains 4 modules: the first one gives general information about international examinations in Business English, and the three other modules cover three levels of BEC (Preliminary, Vantage and Higher) in four language skills. Though the formats of all the three levels are studied, the emphasis is on the Upper-Intermediate level due to the students' linguistic competences. As for the master's degree students, the content of the course in mainly the same, but it is structured in a different way: each module covers one of the four language skills at all levels of BEC. Within this course, also all the levels is considered, but more attention is paid to the Advanced level.

Both courses are aimed at giving theoretical supports and exam information, introducing the structure, content and procedure of the exams, as well as the main strategies, recommendations and techniques to pass them successfully. Much attention is paid to the practical activities, focusing on training. They are completed by students both in class and autonomously. Before completion, each task is described so that the students get comprehensive information about its type (for instance, multiple-choice, matching, note-taking, etc.), aims and tested skills. Besides, the recommended examination techniques are introduced. To provide the students with more information, they are given a reference to the authorized web site, where they can test their English and get sample tests (Cambridge Assessment English, 2019).

At any stage of the subject learning students may face some difficulties (both linguistic and methodological). Therefore, they are asked to give feedback on their strong and weak points and suggest some ways of compensating for these deficiencies.

Answering the question about the importance of international certification in Business English for translators, interpreters and English teachers, 92\% of respondents consider that a specialist in the sphere of linguistics is supposed to have a certificate proving their professional competence. The most frequently mentioned reasons are: confirmation of language skills level, improving the qualification, contributing to the professional growth, having an ability to 
compete at the international market (to find a job in a multinational company, to work or study abroad). A language certificate in the portfolio is a "symbol" of international recognition, which opens better career prospects and develops selfconfidence.

\subsection{EXTRACURRICULAR ACTIVITIES RELATED TO BUSINESS ENGLISH}

The project "I am a Linguist!" was launched in the Higher School of Foreign Languages and Translation to scaffold students in their desire to improve their language knowledge and skills and to guide them professionally. It includes many educational events as well as functioning of academic clubs.

The idea of organizing a contest in which students could compete in their Business English skills came with the necessity to give additional motivation to students. Though the optional courses are quite popular among students, we consider it to be essential to encourage their interest and inspire them. Therefore, the second year students, who are supposed to choose these subjects in future, are invited to take part in the contest.

This event has three stages (or rounds). In the first one all sophomores take part. Lecturers who teach the practical course of English hold this round with their academic groups. The task is usually given as a home assignment, that is a topic for a 2-3 minute monologue, in which participants give their hypothetic ideas about what kind of business they would start up if they had the chance. The talk is assessed by the following criteria: pronunciation (sounds and intonation); grammar (accuracy and complicatedness of structures); vocabulary (accuracy of the use of words, sophistication of lexis); discourse management (ability to speak about the topic in question in a logical way and for the right length of time); presentation skills (ability to speak and behave in public, including dress code). 
Basing on the scores, a lecturer recommends one of the students of the academic group to participate in the second round. It takes place in one week and presupposes completing the tasks on reading and listening of B1-B2 levels. The types of tasks include multiple choice, matching, note-taking. The participants with the 10 top scores are invited to take part in the third round.

In the final the participants get a task to make an oral essay. The topic is announced 30 minutes before performing in public. Students are supposed to give their opinion on a quotation of a famous person. For example: "Time is Money" (Benjamin Franklin); "An investment in knowledge pays the best interest" (Benjamin Franklin); "Let all your things have their places; let each part of your business have its time" (Benjamin Franklin); "The first duty of a human being is to find your real job and do it" (Charlotte Perkins Gilman); "Success has a simple formula: do your best, and people may like it" (Sam Ewing); "Doing your best at this moment puts you in the best place for the next moment" (Oprah Winfrey).

This round is held in a large room, where all those interested are invited. The order of participants is determined by the draw and their performance on the stage is organized in such a way that they don't hear the previous speakers, as they are invited into the room by the volunteers one by one. The 2-3 minute talks are assessed by a panel of lecturers, basing on the same criteria as in the first round.

\section{SUMMARY}

With reference to the work experience, observation, and results of the students' survey, we may conclude that the most serious challenges facing Business English lecturers are caused by students' poor knowledge of General English, insufficient language skills and lack of motivation. The favorable factors are students' personal interest, being oriented at finding opportunities to develop general (cognitive, cultural, communication) and special (professional) skills, being focused on high standards. 
The teachers' tasks are to consider individual interests and expectations of students, to facilitate the process of developing their talents and creative skills. Due to the changes at the labour market, in the social situation and academic environment, the techniques of teaching academic disciplines need to be reconsidered and updated.

\section{CONCLUSIONS}

Thus, modern professional linguistic education could offer better opportunities for learning Business English. One of them is including the subject into the list of obligatory courses. The experience of teaching it, accumulated by a great number of teachers and methodologists all over the world, has produced a lot of aids and methods, which could be employed while teaching students of Linguistics major. What should be taken into consideration by the university lecturers is that such students are supposed to get a more profound and extensive understanding of the subject than students getting non-linguistic professions or people attending courses of Business English at language schools.

The combination of the basic course of Business English, the course of preparation for an international examination and extracurricular activities contribute to educating a many-sided professional personality. The survey data proved that the targets of the academic subjects meet the interests, needs and expectations of future translators, interpreters and English teachers, as they see the real opportunities of how to use the corresponding knowledge and skills in their career.

\section{ACKNOWLEDGEMENTS}

The work is performed according to the Russian Government Program of Competitive Growth of Kazan Federal University. 


\section{REFERENCES}

Abdullina, L. R., Ageeva, A. V., \& Gabdreeva, N. V. (2019). Using the "Flipped Classroom" Model in the Teaching of the Theoretical Disciplines (French Language) at the University. XLinguae, 12(1), 161-169. doi: https:// doi.org/10.18355/XL.2019.12.01XL.12

Akimova, O., Bobyreva, N., Palutina, O., \& Pomortseva, N. (2015). Distance Language Education. Procedia-Social and Behavioral Sciences, 199, 348356. doi: https://doi.org/10.1016/j.sbspro.2015.07.558

Bentley, K. (2011). The Teaching Knowledge Test: Content and Language Integrated Learning Module. Cambridge: Cambridge University Press, 124.

Cambridge Assessment English. (2019). Retrieved from https://www. cambridgeenglish.org/

Eslami, R., \& Ahmadi, S. (2019). Investigating the Role of Educational Media on Secondary School Students' Learning Process Improvement in Jahrom City. Fournal of Humanities Insights, 3(01), 13-6. doi: https://doi.org/10.22034/ jhi.2019.80890

Jabbari, E., Charbaghi, Z., \& Dana A. (2019). Investigating the Effects of Educational and Motivational Education at Different Levels on the Performance and Application of dart throwing. Fournal of Humanities Insights, 3(02), 37-44. doi: https://doi.org/10.22034/jhi.2019.80896

Kashisaz, S., \& Mobarak, E. (2018). The Effects of Private Education Institutes in Providing Modern Financial Knowledge in Developing Countries. Fournal of Humanities Insights, 02(04), 172-8. doi: https://doi.org/10.22034/ jhi.2018.80887

Kheirabadi, M. A., \& Mirzaei, Z. (2019). Descriptive valuation pattern in education and training system: a mixed study. Fournal of Humanities Insights, 3(01), 7-12. doi: https://doi.org/10.22034/jhi.2019.80889 
Kondrateva, I., \& Nazarova, M. V. (2015). Integration of Science and Language in Teaching English. Fournal of English Language and Literature, 61(3), 63-68. doi: https://doi.org/10.7813/jll.2015/6-3/47

Kurbanov, R. A., Gurbanov, R. A. O., Belyalova, A. M., Maksimova, E. V., Leonteva, I. A., \& Sharonov, I. A. (2017). Practical Advice for Teaching of University Students the Mechanisms of Self-Government of Safe Behavior. International Electronic Fournal of Mathematics Education, 12(1), 35-42. Retrieved from https://www.iejme.com/article/practical-advice-for-teaching-ofuniversity-students-the-mechanisms-of-self-government-of-safe

Mahdavi Panah, M. \& Ghaderi, M. A. (2018). Undesirable Effects Of Procrastination From The Perspective Of Islamic Narrations. UCT Journal of Social Sciences and Humanities Research, 6(1), 9-12.

Nakhaee, J., \& Nasrabadi, M. A. (2019). Strategies for Research-Centered Education of Architectural Designing by Examining the ResearchCentered Activities of the Top Universities. Fournal of Humanities Insights, 3(02), 50-6. Retrieved from http://www.jhumanities.net/article_80898_ dcaa625489b5f0ff63aea1583a374ee8.pdf

Proshina, Z. G. (2008). The Theory of Translation (from English into Russian and from Russian into English"). Vladivostok: Far Eastern University. 276.

Pussyrmanov, N., Rystina, I., Bulegenova, B., Askeyeva, G., \& Gabdulina, B. (2018). President Nursultan Nazarbayevs program article "The course towards future: Modernization of public consciousness"-ideology, value and political aspects. Opción, 34(85-2), 824-837.

Sirbu, C. G., Tonea, E., Iancu, T., Pet, E., \& Popa, N. D. (2015). Aspects concerning the usage of modern methods for teaching-learning-evaluation in universities. Procedia-Social and Behavioral Sciences, 182, 550-554. doi: https:// doi.org/10.1016/j.sbspro.2015.04.777 
Yanova, N. (2015). Assessment of Satisfaction with the Quality of Education: Customer Satisfaction Index. Procedia-Social and Behavioral Sciences, 182, 566573.

Zorina, A. V., Vygodchikova, N. N., Gatin, R. G., Nazmutdinova, M. A., \& Gerasimova, O. Y. (2016). Multicultural Education of Multi-Ethnic Students at the Foreign Language Class. International Journal of Environmental and Science Education, 11(18), 10817-10827. Retrieved from https://eric. ed.gov/?id=EJ1120635

Zorina, A. V., Yarullina, A. S., Akhmetova, L. A., Shaimardanova, M. R., Nikishina, S. R., \& Garipova, A. A. (2018). Leadership in the University Student Environment: How to Become a Person-Oriented Leader. International Fournal of Instruction, 11(4), 271-286. doi: https://doi.org/10.12973/ iji.2018.11418a 
Edición Especial Special Issue Octubre 2019 DOI: https://doi.org/10.17993/3ctic.2019.83-2.90-105 